\title{
An Analysis of the Effect of Utilitarian Values on Shopee E- Commerce Satisfaction and Loyalty with SEM-PLS
}

\author{
Nina Valentika \\ Universitas Pamulang, Indonesia
}

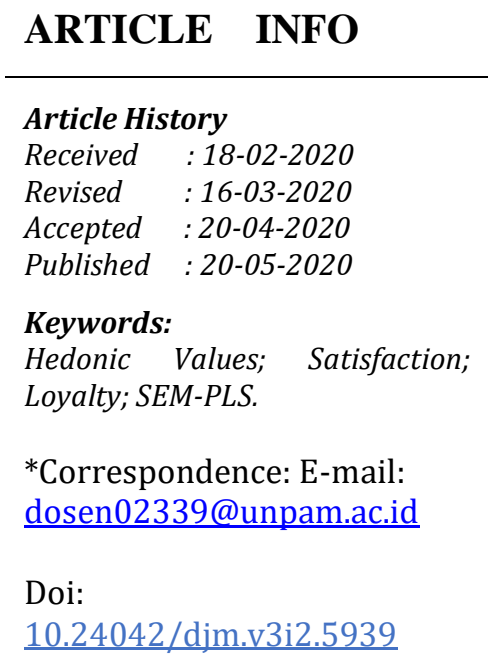

\begin{abstract}
This research examines Shopee consumers who have shopped at least once and are students in the Department of Accounting, Faculty of Economics, Pamulang University. The method used was the Structural Equation Modeling-Partial Least Square (SEM-PLS). The purpose of this research was to examine the direct effect of utilitarian values on satisfaction, examine the direct effect of satisfaction on loyalty, and examine the indirect effect of utilitarian values on loyalty. Based on the results of the research, it can be concluded that there was a significant influence on satisfaction and loyalty, utilitarian values, and satisfaction, as well as utilitarian values and loyalty. There was a significant influence of Utilitarian values and loyalty with satisfaction as an intervening variable.
\end{abstract}

\section{INTRODUCTION}

Along the times, the internet is getting closer to human life. The internet can be used in the business world. The internet used for business transaction activities can be called Electronic Commerce (E-Commerce). One ecommerce that is currently growing rapidly is Shopee. Shopee as e-commerce from Singapore managed to maintain its first position as top e-commerce for ten consecutive quarters based on the ranking in the Playstore. In the second quarter of
2019, Shopee also led the Appstore ranking category.

According to $\mathrm{Wu}$ and Chang (2016), utilitarian values and hedonic values are considered two important things in the perceived values. However, this research was focused on utilitarian values. According to Lien et al. (2011), utilitarian values are price savings, services, time savings, and merchandise selection that can be combined with an assessment of the overall functional benefits. Research by $\mathrm{Hu}$ and Chuang (2012) reveals that 


\section{Desimal, 3 (2), 2020 - 118}

Nina Valentika

cognitive aspects such as the values of money, comfort, and time savings are involved in utilitarian values. The reflection of perceived values perceived by consumers is customer satisfaction. If the values are unsatisfactory, the customer will be disappointed. If the values are in line with customers' expectations, the customers will be satisfied (Kotler and Keller 2016).

According to Sharma and Wang 2015 , user satisfaction in the context of ecommerce and websites illustrates the feelings and attitudes and expectations of users who assume that they have received good service using e-commerce applications and are likely to revisit and repurchase. According to Tankovic and Benazic (2018), customer loyalty is shaped by perceived values and customers' satisfaction.

One of the studies related to ecommerce was conducted by Krisnanda and Rulirianto (2019). Based on Krisnanda and Rulirianto's research (2019), the hedonic shopping values variable has more influence than the utilitarian spending values variable. Research related to utilitarian values and satisfaction was conducted by Nurmala (2016). Based on Nurmala's Research (2016), there is an influence of utilitarian values on satisfaction, hedonic values on satisfaction, and utilitarian and hedonic values on satisfaction. The data analysis method employed by Nurmala (2016) was a simple regression analysis, correlation coefficient, coefficient of determination, partial test, and significance test. Thus, research was needed to see the direct effects of utilitarian on satisfaction and loyalty as well as the indirect effect of utilitarian values on loyalty and satisfaction as the intervening variables. To determine the direct and indirect effects, the Structural Equation ModelPartial Least Square (SEM-PLS) can be used.
The purpose of this research was to examine the direct effect of utilitarian values on satisfaction, examine the direct effect of satisfaction on loyalty and examine the indirect effect of utilitarian values on loyalty with satisfaction as an intervening variable.

\section{METHOD}

The method of this research was in line with Rinaldi's research (2019) which is a quantitative research method through statistical modeling. This research employed Structural Equation ModelPartial Least Square (SEM-PLS). The initial step of the analysis was to estimate the parameters of the structural equation model. Then, the next step was to evaluate the PLS model and measure the significance of the model parameters using the bootstrapping procedure. The outer model and the inner model assessments were used to evaluate the PLS model.

The measurement model evaluation (outer model) is to assess the validity and reliability of the model (Latan and Ghozali, 2012). The execution of SEMPLS required repeated calculation so that the validity and reliability could be met. The reliability measurement used was composite reliability (CR) and the validity measurements used were convergent and discriminant validity. The convergent validity measurement used was the average variance extracted (AVE). The discriminant validity measurement used was cross-loading. A construct is declared valid and reliable if the AVE values are more than 0.5 and the $C R$ values are more than 0.7. In other words, the variables used are valid and reliable or have fulfilled convergent validity and reliability. An indicator is said to be valid or meets the criteria of convergent validity and discriminant validity if it has a loading factor more than 0.7 for the intended construct and has a loading value that is more than the cross-loading values. If the 
model is not feasible, then it should be modified just like Rinaldi's research (2019) by issuing indicators with loading values less than 0.7 to increase the validity and reliability.

The structural model evaluation (inner model) is used to see the predictive power of the structural models. R-Squares for all endogenous latent variables are used to assess structural models with PLS. According to Chin (1998) in Latan and Ghozali (2012), the values of $\mathrm{R}^{2}$ of 0.67 ; 0.33 ; and 0.19 show strong, moderate, and weak models. The evaluation of PLS models can also be done with $\mathrm{Q}^{2}$ predictive relevance. If the values of $Q^{2}>$ 0 , then the research model has predictive relevance.

The population in this research was Shopee online shop visitors in Indonesia. The data source used in this research was the primary data. The data was obtained by distributing online questionnaires. The sampling technique used was simple random sampling. The sample criteria in this research were consumers who have shopped at least once and were students of the Department of Accounting, Faculty of Economics, Pamulang University. The number of samples with an error rate of $10 \%$ was calculated using the Slovin formula, namely:

$$
\begin{gathered}
\mathrm{n}=\frac{\mathrm{N}}{1+\mathrm{N}(\mathrm{k})^{2}} \\
=\frac{90.7 \times 10^{6}}{1+90.7 \times 10^{6}(10 \%)^{2}} \\
\approx 99,99988975 \approx 100 .
\end{gathered}
$$

Where $\mathrm{n}$ is the number of samples, $\mathrm{N}$ is the total population (90.7 million Shopee users in Indonesia), and $\mathrm{k}$ is the error rate used which is $10 \%$.

The measurement of variables of the questionnaire was a Likert scale which is a method of measuring attitudes by expressing agreement or disagreement with certain subjects or objects. The criteria values of the Likert scale measurement were choices of 1 for Strongly Disagree to 5 for Strongly Agree.

\section{RESULTS AND DISCUSSION}

Initial data processing was done using the Smart PLS application version 3. The initial model used in this research is presented in Figure 1.

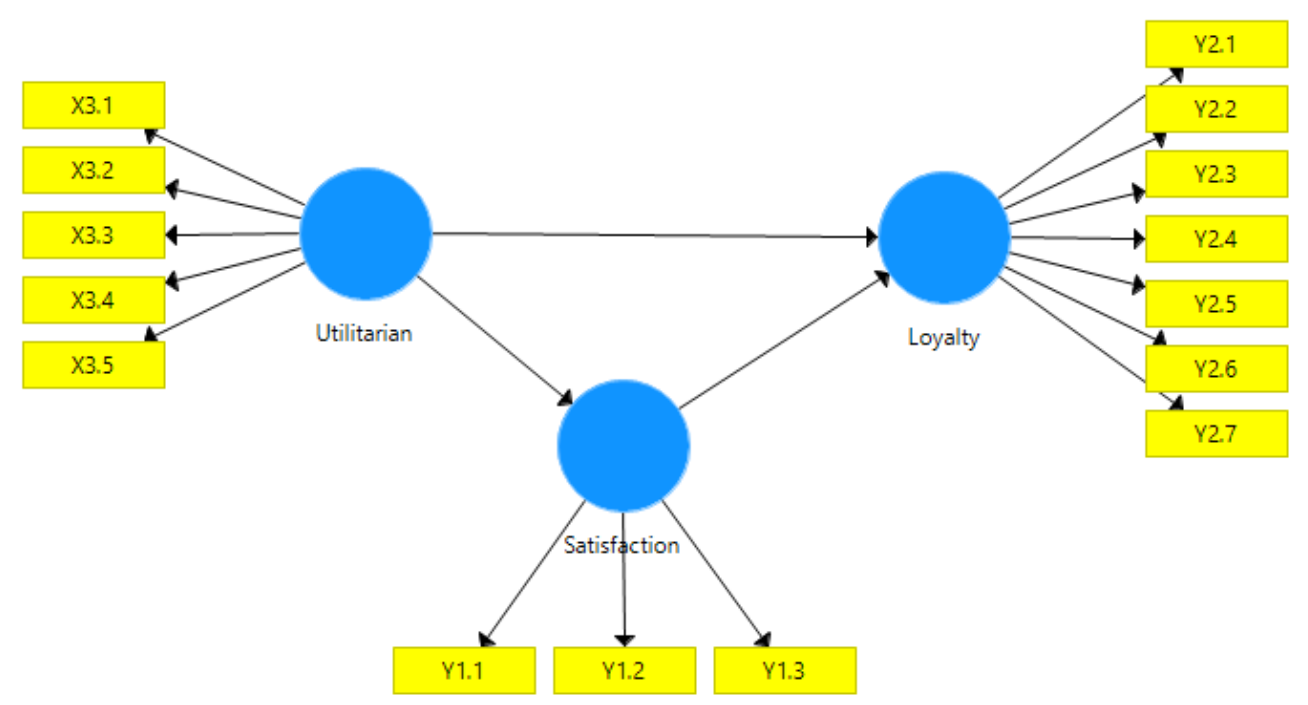

Figure 1. The Initial Research Model

The hypotheses of this research are: $\mathrm{H}_{1.1}$ : Utilitarian values directly affect the satisfaction $\mathrm{H}_{1.2}$ : Satisfaction directly affects loyalty 
$\mathrm{H}_{1.4}$ : Utilitarian Values influence loyalty with satisfaction as an intervening variable.
The results of the loading factor on the indicators in the initial model are presented in Figure 2.

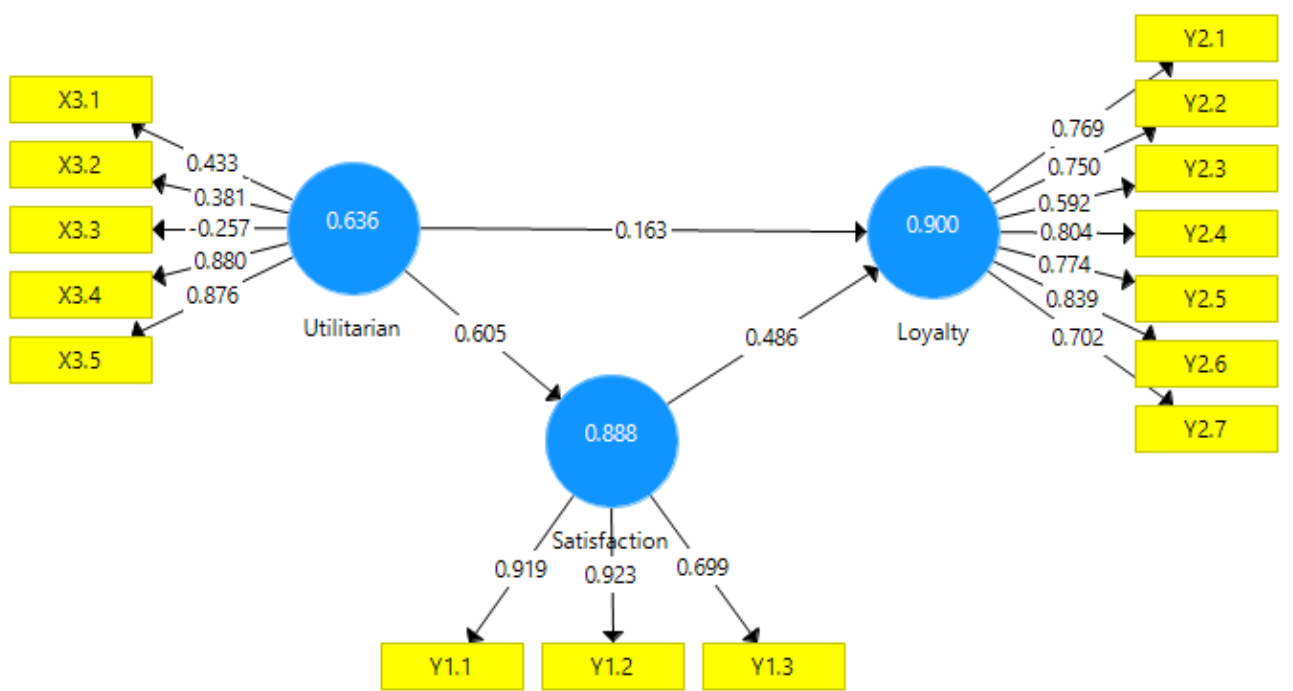

Figure 2. The Loading Factor Results of the Indicators in the Initial Model

Indicators with values less than 0.7 were removed from the model path to increase the validity and reliability. The model after the removal of the indicator was used as the final model of this research. The final model of this research is presented in Figure 3.

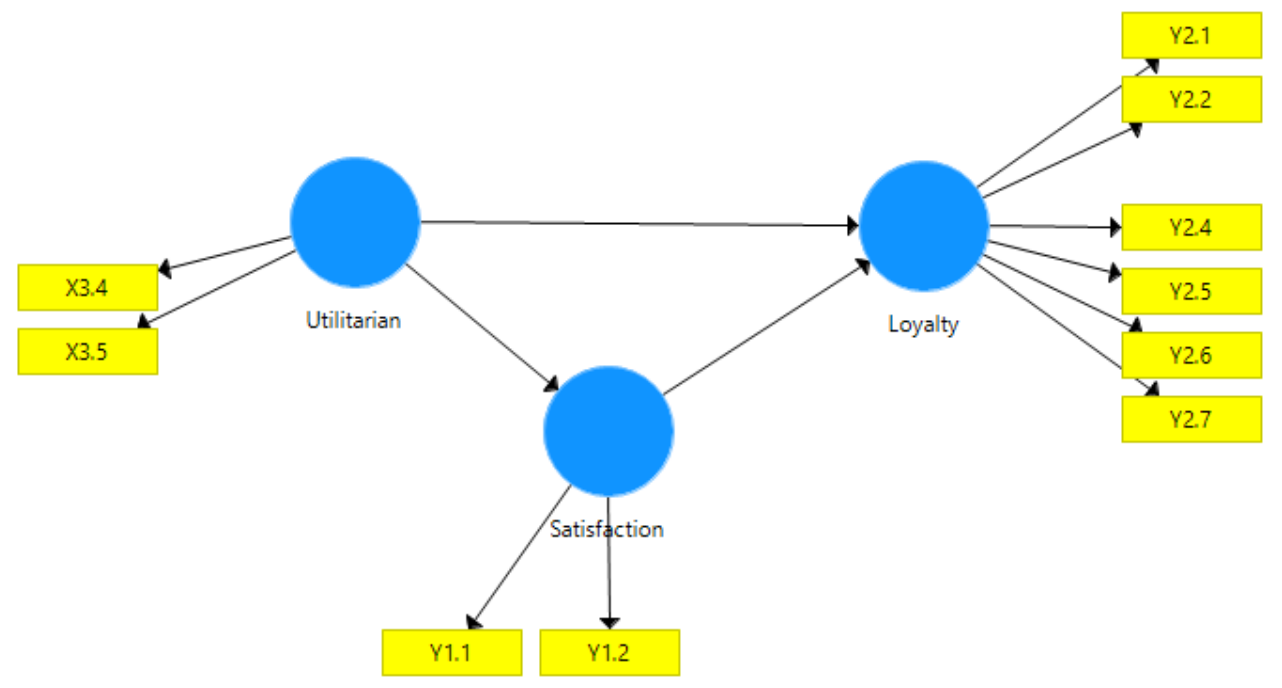

Figure 3. Final Model of the Research

A construct is said to be valid and reliable if the average variance extracted values (AVE) are more than 0.5 (Fornell \& Larcker 1981 in Vinzi et al. 2010) and the composite reliability (CR) is more than 0.7 (Hair et al. 1998 in Vinzi et al. 2010). The AVE and CR values for the final model of this research are presented in Table 1. 
Desimal, 3 (2), 2020 - 121

Nina Valentika

Table 1. AVE and CR Values of the Final Research Model

\begin{tabular}{llll} 
No. & Variable & AVE & CR \\
1. & Utilitarian Values & 0.818 & 0,900 \\
2. & Satisfaction & 0,920 & 0,958 \\
3. & Loyalty & 0,617 & 0,906 \\
\hline
\end{tabular}

Based on Table 1, the smallest AVE value is 0.617 while the smallest CR value is 0,900 . Thus, the variables used in this research were valid and reliable or had met the convergent validity and reliability. An indicator is declared invalid if the loading factor is more than 0.7 toward the objective construct and the loading values must be higher than the cross-loading values (Chin 1998 in Vinzi et al. 2010). The loading and cross-loading values of the final research model are presented in Table 2.

Table 2. Loadings and Cross-Loading Values of the Final Research Model

\begin{tabular}{cccc}
\hline Indicator & Utilitarian Values & Satisfaction & Loyalty \\
\hline X3.4 & 0.90 & 0.56 & 0.38 \\
X3.5 & 0.90 & 0,51 & 0.44 \\
Y1.1 & 0.57 & 0.96 & 0.51 \\
Y1.2 & 0.57 & 0.96 & 0.52 \\
Y2.1 & 0.42 & 0.50 & 0.79 \\
Y2.2 & 0.28 & 0.36 & 0,75 \\
Y2.4 & 0,30 & 0,44 & 0,81 \\
Y2.5 & 0,39 & 0,44 & 0,76 \\
Y2.6 & 0,38 & 0,45 & 0,86 \\
Y2.7 & 0,34 & 0,30 & 0,74 \\
\hline
\end{tabular}

Based on Table 2, it is known that the lowest loading values are Y2.7 of 0.74 and all loading values have the greater values than the cross-loading values so that the indicators used in this research were valid or met the convergent validity and discriminant validity.
According to Chin (1998) in Latan and Ghozali (2012), the values of $\mathrm{R}^{2}$ of $0.67 ; 0.33$; and 0.19 , respectively, showing strong, moderate, and weak models. The $\mathrm{R}^{2}$ of this research is presented in Table 3 .

Table 3. The $\mathrm{R}^{2}$ of the Final Research Model

\begin{tabular}{lc}
\hline Variable & $\mathbf{R}^{\mathbf{2}}$ \\
Satisfaction & 0.35 \\
Loyalty & 0.32 \\
\hline
\end{tabular}

Based on Table3, the values of $\mathrm{R}^{2}$ for the satisfaction variables are 0.35 which means the model can be said as moderate. The $\mathrm{R}^{2}$ values for the loyalty variable are 0.32 which means the model can be said to be weak. Besides seeing the values of $\mathrm{R}^{2}$, the evaluation of the PLS model can be done with $Q^{2}$ predictive relevance. This approach was adopted by PLS using the blindfolding procedure (Latan dan Ghozali 2012). The values of $Q^{2}$ of the final research model are presented in Table4. 
Desimal, 3 (2), 2020 - 122

Nina Valentika

Table4. The Values of $\mathrm{Q}^{2}$ Predictive Relevance of the Final Research Model

\begin{tabular}{lccc}
\hline \multicolumn{1}{c}{ Variable } & SSO & SSE & Q $^{2}$ (= 1-SSE / SSO) \\
Satisfaction & 200.00 & 140.32 & 0.30 \\
Loyalty & 600.00 & 499.29 & 0.17 \\
Utilitarian & 200.00 & 200.00 & \\
\hline
\end{tabular}

All values of $\mathrm{Q}^{2}>0$ indicate that this research model possessed predictive relevance. Next, to measure the significance of the research model, the bootstrapping procedure was performed. The direct effects of the final research with a significance of $\alpha=5 \%$ are presented in Figure 4 and Table 5.

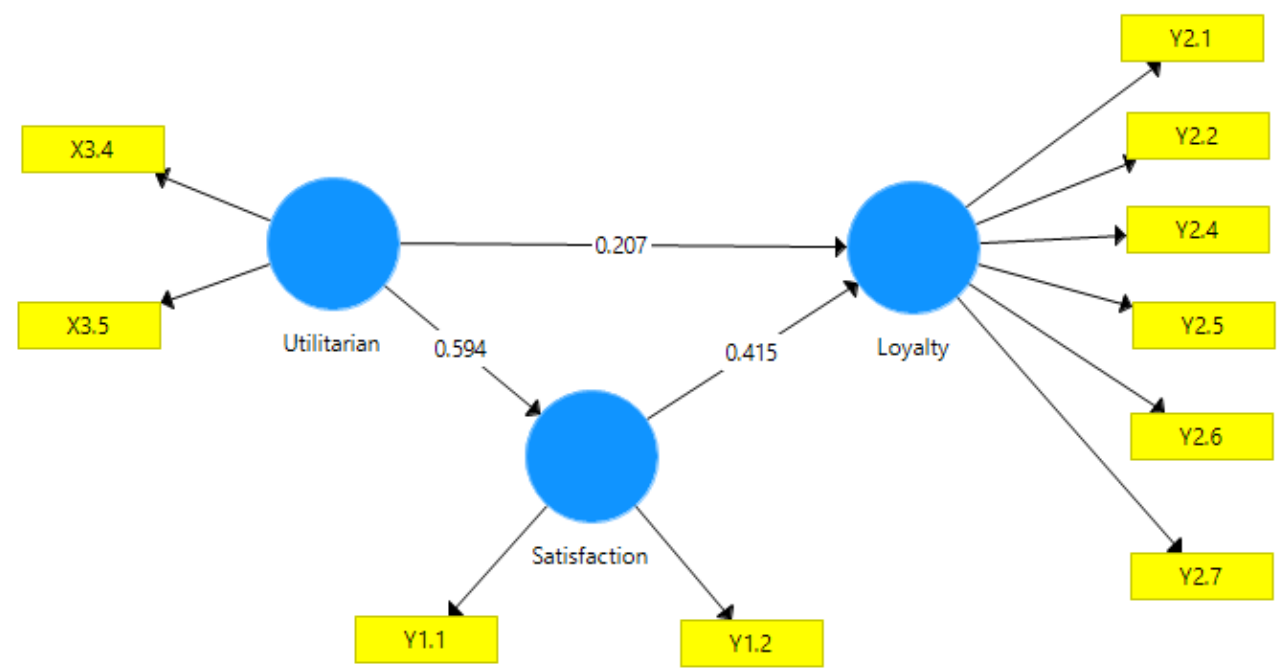

Figure 4. Direct Effects of the Final Research Model

Table 5. Direct Effects of the Final Research Model

\begin{tabular}{lcccccc}
\hline & Original Sample & $\begin{array}{c}\text { Sample } \\
\text { Mean }\end{array}$ & $\begin{array}{c}\text { Standard } \\
\text { Deviation }\end{array}$ & T Statistics & P Values \\
Satisfaction $\rightarrow$ Loyalty & 0.42 & 0.43 & 0.09 & 4.40 & 0.00 \\
Utilitarian $\rightarrow$ Satisfaction & 0.59 & 0.60 & 0.07 & 8.94 & 0,00 \\
Utilitarian $\rightarrow$ Loyalty & 0.21 & 0.22 & 0.12 & 1.77 & 0.08 \\
\hline
\end{tabular}

Based on Table 5, it can be concluded that:

1. The path coefficient obtained between the satisfaction variable and loyalty is 0.42 with a Tstatistic value of $4.40>1.96$ at the significance level $(\alpha)=5 \%$. It can be concluded that there was a significant influence on satisfaction and loyalty. The positive values on the coefficient parameter mean that the higher the level of satisfaction, the higher loyalty will increase.

2. The path coefficient obtained between the Utilitarian Values variable and Satisfaction of 0.59 with a T-statistic value of 8.94> 1.96 at the significance level $(\alpha)=$ $5 \%$. It can be concluded that there was a significant effect between utilitarian values and Satisfaction. The positive values on the coefficient parameter mean that 
the higher the utilitarian values, the higher satisfaction will increase.

3. The path coefficient results obtained between the utilitarian values variable and Loyalty is 0.21 with a T-statistic value of 1.77> 1.96 at the significance level $(\alpha)=$ $5 \%$. It can be concluded that there was a significant influence between utilitarian values and loyalty. The positive values on the coefficient parameter mean that the higher the utilitarian values, the higher loyalty will increase.

This research investigated the influence of utilitarian values on loyalty with satisfaction as an intervening variable. Total indirect effects are presented in Table 6.

Table 6. Total indirect Effects of the Final Research Model

\begin{tabular}{lccccc} 
& $\begin{array}{c}\text { Original } \\
\text { Sample }\end{array}$ & $\begin{array}{c}\text { Sample } \\
\text { Mean }\end{array}$ & $\begin{array}{c}\text { Standard } \\
\text { Deviation }\end{array}$ & T Statistics & P Values \\
$\begin{array}{l}\text { Utilitarian } \rightarrow \text { Loyalty } \\
\text { (with satisfaction as an }\end{array}$ & 0.25 & 0.25 & 0.06 & 3.97 & 0.00 \\
intervening variable) & & & & & \\
\hline
\end{tabular}

Based on Table 6, it is found that there is a significant influence $\mathrm{OF}$ utilitarian values on loyalty with satisfaction as an intervening variable that is equal to 0.25 with a T-statistics value of $3.97>1.96$ at the significance level $(\alpha)=$ $5 \%$. The positive values on the coefficient parameter mean that the higher the utilitarian values, the higher loyalty will increase.

Through SEM-PLS, this research found that there was a positive influence of utilitarian values on satisfaction. The results of this research are similar to the results of Nurmala's research (2016) which uses a partial test (t-test).

Through SEM-PLS, this research found that there was a positive influence between utilitarian values on loyalty both directly and indirectly with satisfaction as an intervening variable, as well as the positive effect of satisfaction on loyalty.

\section{CONCLUSION}

Based on the results of the research, it can be concluded that there is a significant influence of satisfaction on loyalty, utilitarian values on satisfaction, and utilitarian values on loyalty. There is a significant influence of utilitarian values on loyalty with satisfaction as an intervening variable.

\section{REFERENCES}

Latan, H. \& Ghozali, I. (2012). Partial Least Squares: Konsep, Teknik dan Aplikasi SmartPLS $2.0 \quad$ M3. Semarang: Badan Penerbit Universitas Diponegoro.

Hu, F.L. \& Chuang, C.C. (2012). A Study of the Relationship Between The Value Perception And Loyalty Intention Toward An E-Retailer Website. Journal of Internet Banking and Commerce, 17(1), 118.

Krisnanda, S. \& Rulirianto. (2019). Pengaruh Nilai Hedonik dan Nilai Utilitarian terhadap Minat Beli Ulang Online Shop Shopee (studi pada mahasiswa D-IV Manajemen Pemasaran Angkatan 2015 - 2018 Politeknik Negeri Malang. Jurnal Aplikasi Bisnis, 5(1), 214-218.

Kotler, P. \& Keller, K. L. (2016). Marketing Management. 15th Global Edition. Boston: Pearson Education, Inc. 
Lien, C.H., Wen, M.J. \& Wu, C.C. (2011). Investigating the Relationships among E-Service Quality, Perceived Value, Satisfaction, and Behavioral Intentions in Taiwanese Online Shopping. Asia Pacific Management Review, 16(3), 211-223.

Nurmala S. (2016). Pengaruh Utilitarian Value dan Hedonic Value terhadap kepuasan konsumen toserba, 3(1), 183-185.

Rinaldi A. (2019). Model Persamaan Struktural untuk Menganalisis Indikator Kesejahteraan Rumah Tangga. Desimal: Jurnal Matematika, 2(3), 281-288.

Sharma, G. \& Wang, L. (2015). The effects of online service quality of ecommerce Websites on user satisfaction. The Electronic Library, 33(3), 468-485.

Tankovic, A. C. \& Benazic, D. (2018). The Perception of E-servicescape and Its Influence on Perceived Eshopping Value and Customer Loyalty. Online Informa-tion Review, 42(7), 1124-1145.

Vinzi et al. (2010). Handbook of Partial Least Squares: Concepts, Methods and Applications. Newyork: Springer-Verlag Berlin Heidelberg.

$\mathrm{Wu}, \quad$ J.F. \& Chang, Y.P. (2016). Multichannel integration quality, online perceived value and online purchase intention: A perspective of land-based retailers. Internet Research, 26(5), 1228-1248. 